\title{
EFFECT OF TRADE OPENNESS ON ECONOMIC GROWTH IN SUB-SAHARAN AFRICA: DYNAMIC PANEL ANALYSIS
}

\author{
Wycliffe Mugun \\ PhD Candidate, Part-Time Lecturer Kaimosi Friends University College, Kenya \\ Department of Economics
}

Article DOI: $\underline{\text { https://doi.org/10.36713/epra6388 }}$

\begin{abstract}
Theoretically, proponents of traditional trade theories argue that trade openness can enhance economic growth by providing access to goods and services, achieving efficiency in allocation of resources through comparative advantage, creation of employment opportunities and generation of capital that leads to better living standards in terms of higher level of GDP per capita,trade openness may strengthen economic growth through different channels such as efficient allocation of resources. However, owing to the fact that there are limited studies on trade openness, various studies indicate divergent views on the effect of trade openness on economic growth. For this reason, it is not clear whether or not trade openness affect economic growth in Sub-Saharan Africa. The main objective of this study was to investigate the effect of trade openness on economic growth in Sub-Saharan Africa. Control variables used in the regression included oversees development assistance, population growth rate, domestic credit and foreign direct investment. Trade openness, inflation and capital stock were explanatory variables and economic growth the dependent variable. This study was modeled using the Neoclassical Growth theory. Onestep difference Generalized Method of Moments results revealed that trade openness had a positive and significant effect on economic growth, capital stock positive and insignificant relationship, while inflation had positive and insignificant relationship with economic growth in SSA.The study thus recommends that there is a need for improving balance of trade by increasing exports diversification and balanced growth and the policy makers of SSA countries should have to give a priority for trade and investment policies which requires some reforms to adjust with changing economic environment. The study concluded that extra-regional trade spurs higher output than intra-regional trade. This may be due to lack of efficiency in the implementation of trade agreements among the intra-regional constituent countries such as Sub-Saharan African countries and lack of full commitment by the member states governments to trade more intensively.
\end{abstract}

KEYWORDS: Trade openness, economic growth, Sub-Saharan Africa

\subsection{INTRODUCTION}

\subsection{Background of the Study}

Economic growth is the steady course of action through which the productive and fruitful capacity of an economy is improved in due course to produce increasing levels of national output and income (Todaro, Smith,2005). Rapid economic growth and economic development, in general, are the macroeconomic objectives of developing countries into the medium and long-term development. In recent years, a growing number of developing countries have adopted trade reforms. These reforms have been implemented to ensure greater integration into the global economy, and achieve acceptable economic performance. Based on a policy of opening to the outside, the Sub-Saharan Africa economy has been assigned to gradually integrate into the globalization game,Fikadu,(2017).Trade openness refers to the outward and inward orientation of a given countries economy. Outward orientation refers to economies that take considerable advantage of the opportunities to trade with other countries whereas, inward orientation refers to economies that overlook taking or unable to take advantage of the opportunities to trade with other countries (Karen. 2015). According to Ray (2012). effect of trade is much-admired on that it increase competition and enhance efficiency. Trade openness is therefore assumed to be an engine of economic growth 
and countries that liberalize their imports and orient production toward exports are assumed to experience faster growth than those Countries that do not, and a faster rate of opening provides greater prospects for development. However, the effect of trade openness on economic growth has been controversial both theoretically and empirically. Theoretically, proponents of traditional trade theories argue that trade openness can enhance economic growth by providing access to goods and services, achieving efficiency in allocation of resources through comparative advantage, creation of employment opportunities and generation of capital that leads to better living standards in terms of higher level of GDP per capita (Bajwa and Siddiqui, 201; Grossman and Helpman, 1991; Harrison,1996; and Chen, 2009).

\subsection{LITERATURE REVIEW 2.1 Introduction \\ 2.2 Empirical Literature 2.2.1 Trade Openness and Economic Growth}

Osei et al (2012) investigated the effects of trade openness on economic growth in African countries. The study used a Cobb-Douglas production function as in Miller and Upadhyay (2000) to estimate the impact of FFDI, exchange rate, capital labor ratio and trade openness on GDP for 38 African countries in 2008. Data were transformed to natural $\operatorname{logs}$ and estimated using alternative panel model which included on or two way fixed or random effects models. The results found trade openness having a positive relationship with GDP.The variables under study included gross domestic product, foreign direct investment, exchange rate, capital, labour and trade openness. The study could have generated more information had it included other variables such as financial development which also affects economic growth.

Salama and Moza (2019) examined trade openness and economic growth impact in Tanzania for the period 1981 to 2017. The study utilized cointegration and vector error-correction mechanism (VECM) approach to test the relationship between trade openness and economic growth and granger causality test to examine the casual relationship between the variables. Unit root tests showed that the variables were integrated after taking first difference, the Johansen co-integration result showed that the variables were co-integrated. The VECM estimate showed that there is positive long run relationship between trade openness and economic growth in Tanzania over the study period, this positive result of trade openness is possibly attributable to the fact that Tanzania unlocked its borders to international traders.
In addition, granger causality test revealed that there is no causal relationship between trade openness and economic growth in Tanzania. Based on this findings the study recommended that government should encourage the production of domestic product for export purpose by developing more domestic industries and attract more investors in the economy.

\section{RESEARCH METHODOLOGY \\ 3.1 Introduction}

This chapter presents the methodology that was employed in this study. It entails the research design, theoretical framework, empirical model, definition and measurement of variables, data sources and data analysis.

\subsection{Diagnostic Tests}

To examine whether fixed and or random effects in the panel data, joint validity of fixed and period effects and Hausman's test were conducted.

\subsubsection{Panel Unit Root Test}

According to the IM Pesaran and Shin test results presented in the appendix in table 2 , shows that the test statistics for the variables natural log of gross domestic product, population growth rate, natural log of gross capital formation, natural $\log$ of domestic credit and natural log of inflation were statistically significant at one percent, while foreign direct investment and oversees development assistance were statistically significant at 5 percent. These implies that these variables were stationary at level.However,test statistics for variables trade openness was not statistically significant. This suggests that these variable was not stationary at level and had to be differenced at least once for them to become stationary. The table indicates hat IPS panel unit root test after including constant plus trend population growth rate, natural $\log$ of gross capital formation, natural log of domestic credit, natural log of inflation were stationary at one percent level while natural log of oversees development assistance was stationary at 5\% level of significance. After including constant plus trend, variables natural log of gross domestic product, foreign direct investment, trade openness, were statistically insignificant implying that they were not stationary and had to be differenced at least once for them to become stationary. Variables that could be considered not to be stationary at level in accordance with IPS was trade openness. When this variable was differenced once they became stationary suggesting that they were integrated of orderI(1).Thus panel unit root tests results in table 3.1 shows that variables on trade openness and economic growth study have mixed orders of integration. Some variables were integrated of order $\mathrm{I}(0)$ while others were integrated of orderI(1). 


\subsubsection{Test for Autocorrelation}

The p-values give the probability of correctly rejecting the null hypothesis of no autocorrelation. It is required that the $\mathrm{AR}(1)$ tests of first order autocorrelation rejects the null, while the tests for second order autocorrelation fails to reject the null hypothesis of no autocorrelation,Arellano and Bond 1991,1998).Therefore the system GMM estimator is consistent only when second order autocorrelation is not significant. Although first order correlation need not be zero. The hypothesis of the presence of autocorrelation of order one is accepted for the estimates results in the appendix section are presented in tables 4.5,4.6 and 4.7 at one percent level of significance. While autocorrelation for order two is found to be absent in all the equations as shown in table 1 in the appendix section. This shows that the chosen lags are valid instruments for the model specifications. Considering together the various statistical tests that have been conducted satisfy the key assumptions of SGMM and DGMM estimations, this model is therefore an appropriate statistical generating mechanism.

\subsubsection{Sargan Test for Overidentification}

The null hypothesis states that over identification restrictions are valid. To correct for over identification some instruments would be dropped to make the estimation less restricted this could be done by adjusting the number of the lags (Arellano and Bond, 1999, Gibbons and Overman, 2012).The p-value test for the one-step difference GMM in table 4.5,4.6 and 4.7 is 0.0000 which is less than the $5 \%$ level of significance and as such the null hypothesis that over identifying restrictions are valid is not accepted. The Sargan's test reflects the goodness of fit of the model. According to Baum(2013), when using GMM estimation the r-squared is no more bounded between 0 and 1,there is no measure of goodness of fit except checking the validity of the instruments.

\subsection{RESULTS AND DISCUSSION} 4.1 Descriptive Statistics

In the appendix section,table 4 shows the results of the normality test and descriptive statistics of the variable under study.From the diagram gross domestic product had a mean of 7.1047, a maximum of 10.0407, a minimum of 4.8546587 with a standard deviation of 1.084353. Gross capital information had a mean of 5.141826, a maximum value of 6.311735 , a minimum of 0.0000 and standard and deviation of 1.355355 .

Domestic credit had a mean of 5.252732, a maximum value of 6.329721 , a minimum value of
0.0000 with a standard deviation of 1.176640 . Whereas inflation rate had a mean of 5.219661, a maximum value of 6.295266 , with a minimum value of 0.0000 and standard deviation of 1.020803.Official development assistance had a mean value of 5.352815, a maximum value of 6.345636 , a minimum value of 0.0000 with a standard deviation of 0.978101.Population growth rate of the other side had a mean value of 2.549233 , a maximum value of 4.654911, a minimum value of -2.628656 and with a standard deviation of 0.907697 .Trade openness had a mean a value of 73.40129 , a maximum of 225.0231, minimum of 0.0000 and standard deviation of 35.50063. Foreign direct investment had a mean value of $7.85 \mathrm{E}+08$, a maximum of $1.00 \mathrm{E}+10$, a minimum of $7.40 \mathrm{E}+09$ and with a standard deviation of 1.59E+09. Skewness measures the direction and degree of asymmetry. In this study figures indicate normal curves for all the variables with negative values of skewness indicating a tail to the right except for gross domestic product, trade openness and foreign direct investment. On the other hand, kurtosis measures the heaviness of the tails of a distribution. From the kurtosis results in the appendix, gross domestic product has a kurtosis value of less than three which means the variable has platykurtosis distribution, fatter middles or fewer extreme values. Whereas variables such as gross capital formation, domestic credit, inflation rate, official development assistance, population growth rate, trade openness and foreign direct investment have kurtosis value of more than three implying that they have heavier or thicker tails than the normal, meaning they have leptokurtosis distribution. 
DYNAMIC PANEL DATA ESTIMATION

Effect of Trade Openness on Economic Growth in SubSaharan Africa: One-Step Difference GMM Table 4.1 Trade Openness and Economic Growth in SSA

\begin{tabular}{|c|c|c|c|c|c|c|}
\hline \multicolumn{7}{|c|}{ Dynamic panel-data estimation, one-step difference GMM } \\
\hline \multicolumn{3}{|c|}{ Group variable: id } & \multicolumn{4}{|c|}{ Number of obs $=494$} \\
\hline \multicolumn{3}{|c|}{ Time variable : yr } & \multicolumn{4}{|c|}{ Number of groups $=38$} \\
\hline \multicolumn{3}{|c|}{ Number of instruments $=91$} & \multicolumn{4}{|c|}{ Obs per group: $\min =13$} \\
\hline \multicolumn{3}{|c|}{$\mathrm{F}(7,487)=121.60$} & \multicolumn{4}{|c|}{ avg $=13.00$} \\
\hline \multicolumn{3}{|c|}{ Prob $>F=0.000$} & \multicolumn{4}{|c|}{$\max =13$} \\
\hline lngdp & Coef. & $\begin{array}{l}\text { Std. } \\
\text { Err. }\end{array}$ & $\mathrm{t}$ & $\mathrm{P}>|\mathrm{t}|$ & \multicolumn{2}{|c|}{$\begin{array}{l}\text { [95\% Conf. } \\
\text { Interval] }\end{array}$} \\
\hline $\begin{array}{l}\text { Ingdp } \\
\text { L1. }\end{array}$ & .6574922 & .047739 & 13.77 & 0.000 & .5636925 & .751292 \\
\hline topen & .006449 & .0010806 & 5.97 & 0.000 & .0043257 & .0085722 \\
\hline fdi & $-1.41 \mathrm{e}-11$ & $1.44 \mathrm{e}-11$ & -0.98 & 0.327 & $-4.23 e-11$ & $1.41 \mathrm{e}-11$ \\
\hline Innoda1 & -.0445165 & .0232475 & -1.91 & 0.056 & -.0901942 & .0011613 \\
\hline popl & .0569885 & .0400991 & 1.42 & 0.156 & -.0218 & .135777 \\
\hline Indom1 & -.0115177 & .0127931 & -0.90 & 0.368 & -.0366541 & .0136187 \\
\hline $\mathrm{yr}$ & .0050942 & .0025474 & 2.00 & 0.046 & .0000889 & .0100995 \\
\hline \multicolumn{7}{|c|}{ Instruments for first differences equation } \\
\hline \multicolumn{7}{|c|}{$\begin{array}{l}\text { GMM-type (missing=0, separate instruments for each period unless } \\
\text { collapsed) }\end{array}$} \\
\hline \multicolumn{7}{|c|}{$\mathrm{L}(1 / 14) . \mathrm{L} \cdot \operatorname{lngdp}$} \\
\hline \multicolumn{7}{|c|}{$\begin{array}{l}\text { Arellano-Bond test for AR(1) in first differences: } \mathrm{z}=-6.54 \mathrm{Pr}>\mathrm{z}= \\
0.000\end{array}$} \\
\hline \multicolumn{7}{|c|}{$\begin{array}{l}\text { Arellano-Bond test for AR(2) in first differences: } \mathrm{z}=-0.99 \mathrm{Pr}>\mathrm{z}= \\
0.321\end{array}$} \\
\hline \multicolumn{7}{|c|}{$\begin{array}{l}\text { Sargan test of overid. restrictions: } \operatorname{chi} 2(84)=181.23 \text { Prob }>\text { chi } 2= \\
0.000\end{array}$} \\
\hline (Not rob & t not & ened b & $\overline{a n t}$ & 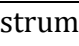 & & \\
\hline
\end{tabular}

of foreign direct investment, official development assistance, population growth rate and domestic credit and other explanatory variables such as trade openness, gross capital formation and inflation.

From the table 4.1, the lagged variable of economic growth has positive and statistically significant relationship with current economic growth at $1 \%$ level of significance. The coefficient of the lagged dependent variable which is 0.65749 postulates the speed of adjustment which represents lag effect. This suggests that a $1 \%$ increase in economic growth will affect growth by $0.66 \%$ increase in the current period. This statistically significant lagged economic growth variable indicates that previous level of economic growth encouraged the current level of economic growth. Previous economic growth would have profound effects, not just inside each country, but for the rest of SSA region. Such effects are a combination of new market opportunities arising from enhanced purchasing power and greater competitiveness of these economies as producers of selected products.

The null hypothesis of zero significance of effect of trade openness on economic growth is rejected $1 \%$ level of significance with a coefficient of 0.0064. This implies that trade openness influences economic growth by a rate of change of $0.064 \%$.The coefficient of foreign direct investment had a negative and statistically insignificant relationship with economic growth. Whereas official development coefficient had a negative and statistically significant relationship with economic growth at 5\% level of significance. This implies that ODA influences economic growth in SSA by rate of change negatively of 4.45\%.Population growth rate had positive and insignificant relationship with economic growth. This implies that the null hypothesis of zero significance of the effect of population growth rate is not rejected. Meaning that population growth rate does not play any role in determining economic growth in Sub-Saharan Africa. Domestic credit coefficient was not significantly different from zero. Results indicate negative and insignificant relationship between domestic credit and economic growth implying that domestic credit does not play any role in determining economic growth in SSA.Trade openness had positive and statistically significant relationship with economic growth in SSA. Meaning that trade openness plays a greater role in determining economic growth in SSA.

Results are consistent with Fikadu (2017), Muhammad and Toseef (2015), Dobre (2008), Mbabazi and Morrissey (2004) whose findings revealed that openness of an economy can positively influence openness on economic growth in Sub-Saharan A

The study had four control variables which comprised 
economic growth because of the flow of the goods and investments across borders through international trade could be an effective means of diffusion of technology at the international trade level and it plays an important role in maintaining long term sustainable rate of productivity growth.Further, according to Zekarias (2016), from the H-O model, trade openness benefits small economies than large economies because small economies cannot affect the world supply hence world price. This means that influence on the world supply is insignificant to affect world demand and price levels. Majority of SSA countries are price takers in the global market.Additionally, Fikadu (2017) and Krugman and Obstfeld (2007) claim any country gains from international trade at least in the form of comparative advantage. Although most of this countries are small to impact the world, foreign trade has benefited them significantly. Most of the time, the SSA region faces trade deficit but the contribution of trade growth is positive and significant. The reason could be that they import more of capital goods than consumer goods. This signals how foreign trade integration is important for the continuous economic growth of the region. Empirically, the work of Fikadu (2017) and Sala (2014) confirms these findings.

Results are also in tandem with Babatunde and Bolade(2020) who examined trade openness and economic growth in Nigeria and results indicated that trade openness had positive effect on economic growth in Nigeria, with an evidence of a long-run relationship. Consistent also with Malefa and Odhiambo (2018), Salama and Moza (2019), Ajayi and Araoye (2019), Osei-yeboah et al (2012) who examined the impact of trade openness on economic growth of Pakistan using an autoregressive distributed lag model and found that trade volume, investment and human capital have a significant impact on economic growth.

However, results are contrary to the empirical findings of Dowrick and Golley (2004), Mputu (2016); Haystad and Jensen (2015), Sundaram and Arnim (2008) and Chantal et al (2011).Also Adnan and Lau (2015) whose results found out that trade openness index negatively impacts on economic growth in the long run.Saibu (2004) who found a unidirectional relationship between openness and economic growth. Therefore, from the above findings of trade openness, we can understand that outward-oriented economies exhibit faster economic growth by allowing efficient allocation of resources, economies of scale, providing access to new technology and by creating business opportunities which improve the living standards of Sub-Saharan Africa countries.From the study therefore, the study rejects the null hypothesis and accept that trade openness effects economic growth because trade openness is statistically significant and positively affects economic growth is Sub-Saharan Africa.

\section{Effect of Capital Stock on Economic Growth in Sub-Saharan Africa} One-Step Difference GMM Table 4.2 Capital Stock and Economic Growth in SSA

\begin{tabular}{|c|c|c|c|c|c|c|}
\hline \multicolumn{7}{|c|}{ Dynamic panel-data estimation, one-step difference GMM } \\
\hline \multicolumn{3}{|c|}{ Group variable: id } & \multicolumn{4}{|c|}{ Number of obs $=494$} \\
\hline \multicolumn{3}{|c|}{ Time variable $: \mathrm{yr}$} & \multicolumn{4}{|c|}{ Number of groups $=38$} \\
\hline \multicolumn{3}{|c|}{ Number of instruments $=91$} & \multicolumn{4}{|c|}{ Obs per group: $\min =13$} \\
\hline \multicolumn{3}{|c|}{$F(7,487)=141.37$} & \multicolumn{4}{|c|}{ avg $=13.00$} \\
\hline \multicolumn{3}{|c|}{ Prob $>F=0.000$} & \multicolumn{4}{|c|}{$\max =13$} \\
\hline $\operatorname{lngdp}$ & Coef. & Std. Err. & $\mathrm{t}$ & $\mathrm{P}>|\mathrm{t}|$ & {$[95 \% \mathrm{Col}$} & [nterval] \\
\hline $\begin{array}{l}\text { lngdp } \\
\text { L1. }\end{array}$ & .6108137 & .0502296 & 12.16 & 0.000 & .5121203 & .7095072 \\
\hline $\operatorname{lngcf1}$ & .0171387 & .0144535 & 1.19 & 0.236 & -.0112603 & .0455376 \\
\hline topen & .0057821 & .0010807 & 5.35 & 0.000 & .0036587 & .0079055 \\
\hline lnnoda1 & $\begin{array}{c}- \\
.0444324\end{array}$ & .0230281 & -1.93 & 0.054 & -.0896792 & .0008143 \\
\hline popl & .0601777 & .0394633 & 1.52 & 0.128 & -.0173617 & .1377171 \\
\hline lndom1 & $\begin{array}{c}- \\
.0139905\end{array}$ & .0127215 & -1.10 & 0.272 & -.0389862 & .0110053 \\
\hline $\mathrm{yr}$ & .0063969 & .0025444 & 2.51 & 0.012 & .0013976 & .0113961 \\
\hline
\end{tabular}

Instruments for first differences equation

GMM-type (missing=0, separate instruments for each period unless collapsed)

L(1/14).L.lngdp

Arellano-Bond test for AR(1) in first differences: $\mathrm{z}=-6.32 \operatorname{Pr}>\mathrm{z}=0.000$

Arellano-Bond test for AR(2) in first differences: $\mathrm{z}=-1.07 \mathrm{Pr}>\mathrm{z}=0.283$

Sargan test of overid. restrictions: $\operatorname{chi} 2(84)=184.13$ Prob $>$ chi $2=0.000$

(Not robust, but not weakened by many instruments.)

Source:Reseach data

The second objective of the study was to examine the effect of capital stock on economic growth in Sub-Saharan Africa. The study employed the onestep difference generalized method of moments dynamic panel developed by Arellano and Bond(1991). Results from table 4.2 revealed that the lagged variable of economic growth has positive and significant coefficient at $1 \%$ level of significance. The coefficient of lagged dependent variable which is 0.6108 postulates the speed of adjustment which represents lag effect. This suggests that a one percentage increase in economic growth will affect growth by 0.61 percent increase in the current period. This statistically significant lagged economic growth encourages the current level of economic growth. From the diagram the coefficient of gross capital formation was not significantly different from zero. Gross capital formation had positive and insignificance relationship 
with economic growth. The statistical insignificance implies that gross capital formation does not play any role in determining economic growth in Sub-Saharan Africa.

On the other hand, the null hypothesis of zero significance of effect of trade openness on economic growth is rejected at $1 \%$ level of significance with a coefficient of 0.0057821 . This implies that trade openness influences economic growth by a rate of change 0.006 percent. Also official development assistance coefficient of -0.044432 has a statistical significant negative effect on economic growth according to the results on table 4.6. This means that a $1 \%$ change in official development assistance causes economic growth to change by $0.44 \%$ negatively. The coefficient of population growth was not significantly different from zero. Population growth rate has positive and insignificant relationship with economic growth. This implies that the null of zero significance of effect of population growth on economic growth is not rejected but accepted. Also meaning that population growth rate does not play any role in determining economic growth in Sub-Saharan Africa. On the other hand, domestic credit had negative and insignificant relationship with economic growth. This means that domestic credit does not play in any role in determining economic growth in Sub-Saharan Africa.

From the study, gross capital formation had positive insignificant relationship with economic growth. This implies that the coefficient of gross capital formation was not significantly different from zero. This implies that gross capital formation was not an important determinant on economic growth in SSA.

Results are consistent with Gisore (2014), Fikadu (2017) who found positive effect of capital stock on economic growth in SSA from 1990 to 2015 study period. Again this supports theoretical expectations and empirical work of Muhammad and Toseef (2015), Pigka-balanika 2013, which postulates a significant positive influence of capital on economic growth. It also agrees with a neoclassical framework in which they believe that more equipment enables workers to produce more output because from CobbDouglas production function labour is combined with output to produce goods and services and it implies increasing returns to capital and labor. Workers need machine, tools and factories to work and use of these capitals makes the worker more productive. This means that investment increases

the higher will be the output growth. The implication of the above results is that when there is a fall in the capital which results in a fall in investment in some of these SSA countries and this has resulted in the slow rate of growth in these counties over the years.
Additionally, as capital for infrastructure in the manufacturing industry increased, the value on exported goods will also increase GDP per capital for Sub-Saharan African countries, Fikadu (2017).

Results are also in tandem with Ofosuah (2014) who found that private investment positively affected economic growth in SSA. Even though the fixed effect results were not significant, they had a positive effect on economic growth. These results of Ofosuah (2014) were also consistent with the growth theory. Capital accumulation or investment, according to theory propels growth. Other consistent results are Halima (2015), Drezgic (2008), Limam and Miller (2003) who found that capital accumulation had positive effect on economic growth. Capital accumulation involves increased spending of country's savings on capital goods that are necessary for production. An increase in capital investment is likely to increase labor productivity if it promotes technological progress. The resulting increase in aggregate output leads to improvement in GDP growth and standards of living. Other in tandem results is Githiga (2014).

Results are however not in tandem with Semwanga (2011) whose results found that coefficient of domestic capital had negative and significant relationship with economic growth in Uganda. This could be results of negative effects that come with foreign investments like stiff competition and pressures on the available resources, market and shift in the use of the technology. Other contrary results are Josephat and Oliver(2000) and Kweka (1999) found the relationship between investment expenditure and growth in Tanzania to be negative. Therefore the study does not reject the null hypothesis but rather accepts the null which states that gross capital formation has no effect on economic growth in Sub-Saharan Africa, because gross capital formation is statistically insignificant and positively affects economic growth in Sub-Saharan Africa.

\section{Effect of Inflation on Economic Growth in Sub-Saharan Africa: One-Step Difference GMM}

The third objective of the study was to examine the effect of inflation on economic growth in SubSaharan Africa. The study employed one step difference Generalized method of moments dynamic panel developed by Arellano and Bond (1991) for the period from 2004 to 2018. They used trade openness, official development assistance, population growth rate and domestic credit as the control variables. Results from the table 3 in the appendix section indicated that the lagged economic growth had positive and statistical significant relationship with economic growth in the 
current period. The lagged variable of economic growth has positive and significant coefficient at 1 per cent level of significance. The coefficient of the lagged dependent variable which is 0.6342 postulates the speed of adjustment which represents lag effect. This suggest that a one percentage increase in economic growth will affect growth by 0.63 percent increase in the current period. This statistically significant lagged economic growth indicates that previous levels of economic growth encourage the current level of economic growth. The coefficient of inflation was not significantly different from zero.

Inflation coefficient had positive and statistically insignificant relationship with economic growth in Sub-Saharan Africa. The statistical insignificance of inflation implies that inflation variable does not play any role in determining the economic growth in SSA.The null hypothesis of zero significance of effect of trade openness on economic trade is rejected at 1 percent level of significance with a coefficient of 0.0057 . This implies that trade openness influences economic growth by a rate of change of 0.006 percent. The coefficient of official development assistance was not significantly different from zero. The variable had negative and statistically insignificant relationship with economic growth. This implies that official development assistance does not play any role in determining economic growth in Sub-Saharan Africa. The null hypothesis on the effect of population growth on economy was not rejected. Population growth rate had positive and insignificant relationship with the economic growth. Population growth coefficient was not significantly different from zero. Also domestic credit had negative and insignificant relationship with economic growth in SSA. The coefficient for domestic credit was also not significantly different from zero. This also meant that domestic credit does not play any role in determining economic growth in SSA. From the above table 4.7 inflation rate had a positive and statistical insignificant relationship with economic growth in SSA. The null hypothesis on the effect of inflation on economic growth was not rejected but rather accepted.

Results are consistent with Abebe (2014) whose findings indicated that inflation rate had a positive and insignificant effect on commercial bank performance in Ethiopia. This may suggest that due to the inability of banks to accurately predict the levels of inflation, the banks lose the opportunity to benefit from the inflationary environment to increase the profits. Results are in tandem with Fikadu (2017) who found coefficient of inflation to have positive effect on economic growth. The outcome is inconsistent with the expectation and endogenous growth theory which argues that variables like inflation that decrease the rate of return, which in turn reduces capital accumulation and decreases the growth rate and consistent with Keynesian theories which considers inflation as a reflection of high aggregate demand. According to this findings, stable inflation may foster investments and economic growth by promoting the efficiency use of productive resources. Other in tandem results are Aminu et al (2014) whose results found that inflation has high positive correlation with economic growth in the South Asian countries, Taleb and Hala(2019) and Hidayat (2014).

However, results are contrary to Halima (2015) who found negative and statistically insignificant relationship with economic growth in East African countries. And the signs of inflation coefficient were consistent with a prior expectation and economic theory. The negative coefficient of inflation is based on the fact that an increase in the price levels reduces GDP growth through its negative effects on aggregate demand. An increase in inflation also increases the cost of production, thereby reducing economic growth.Munyambonera (2012) also found inconsistent results. Inflation variable had a negative effect on bank profitability. The negative effect reflects the inability of bank mangers to forecast inflation in their cost structure to realize profits, Panayiotis et al (2005).

Other contrary results are Kormandi and Meguire (1985), Grimes (1991), Fischer (1993), DeGregorio (1993), Gylfason and Hebertsson (2001), Valdovinoz (2003) and Guerrero (2004) revealed that inflation had negative effect on economic growth. Fischer (1993) reported that a negative relationship exists between inflation, economic growth and budget deficits. He found the direction of casualties to flow from macroeconomic policies such as inflation and budget deficits on economic growth. According to Fischer's study, inflation reduces growth, investments and productivity; public deficit reduces both capital accumulation and productivity increases.

Also, Bruno and Esterly (1996) found negative and insignificant relationship between inflation and economic growth. Also contrary results are Anochiwa and Maduka (2014). Their results on the test showed that there is a non-linear relationship between economic growth and inflation and the co-efficient of inflation was negative and statistically insignificant in relationship.Ocharo (2013) study macroeconomic stability had a negative and statistically significant coefficient at 10 percent. This is an indication that an unstable macroeconomic environment discourages economic growth. Inflation was used to test for macroeconomic stability. Other inconsistent findings are those of Borensztein et al (1998), Ayanwale and 
Awolowo (2007) and Macias et al (2009).From the results therefore, the study does not reject the null hypothesis but rather accepts the null hypothesis which states that inflation has no effect on inflation growth in Sub-Saharan Africa because inflation is statistically insignificant and does not affect economic growth in SSA.

\section{CONCLUSION AND POLICY RECOMMENDATIONS Conclusion}

The study analyzed the effect of trade openness on economic growth for 38 SSA countries using the data from world development indicators (2020) database from 2004 to 2019. The study concludes that extra-regional trade spurs higher output than intraregional trade. This may be due to lack of efficiency in the implementation of trade agreements among the intra-regional constituent countries such as SSA African countries and lack of full commitment by the member states governments to trade more intensively. In conclusion, SSA suggested to actively be engaging in international trade since it facilitates technology transfer exchange of information and opportunities to realize economies of scale and high volume of investment. Therefore, increasing trade openness is useful channel for SSA to boost private sector development and economic growth in the long run.

\section{Policy Recommendation}

From the study findings, trade openness has a significant positive effect on economic growth in SubSaharan African countries. The study therefore recommends policy to be implemented. First, there is a need for improving balance of trade by increasing exports diversification and balanced growth. These countries should aim at industrializing so as to export processed products to reap the full benefit of integration into the global market. Also, the policy makers of SSA countries should have to give a priority for trade and investment policies which requires some reforms to adjust with changing economic environment. The policies should be geared towards more free trade and the elimination of trade barriers by being a member of regional and international trade integrations.

\section{REFERENCES}

1. Abebe, T. (2014). Determinants of Financial Performance: An Empirical Study on Ethiopian Commercial Banks. (Unpublished Masters Thesis on finance and accounting), Jimma University, Jimma Ethiopia.

2. Adnan, Q.M.H, \& Lau, W.(2015). Trade openness and economic growth: Empirical evidence from
India. Journal of Business Economics and Management, Volume 16(1), pp. 188-205

3. Ajayi, E.O. \&Araoye,F.E. (2019). Trade openness and economic growth in Nigeria. International Journal of Economics and Financial Management.Vol 4, No 2 pp 50-63. www.iiardpub.org

4. Anochiwa, L.I., and Maduka, A. (2015) Inflation and Economic Growth in Nigeria: Empirical Evidence. Journal of Economics and Sustainable Development.Vol 6, No 20. PP 113-121. www.iiste.org.

5. Arellano, M., and Bond, S. (1991).Some Tests of Specifications for Panel Data: Monte Carlo Evidence and An Application to Employment Equations. Review of Economic Studies 1991, 58, PP. 277-297.

6. Ayanwale, B.A. and Awolowo, O. (2007). Foreign direct investment and economic growth: evidence from Nigeria. AERC Research Paper.165, African economic research consortium, Nairobi.

7. Babatunde, A. and Bolade O. (2020).Trade Openness and Economic Growth in Nigeria. Journal of Economics and Sustainable Development. Vol. 11, no 4 PP 165-171. www.iiste.org.

8. Balanika,P.(2013).The impact of trade openness on economic growth evidence in developing countries.(Unpublished Masters thesis in economics and business), Erasmus university Rotterdam, Erasmus school of economics.

9. Bajwa, S., Siddiqui,W.M. (2011). Trade openness and its effect on economic growth in selected south Asian countries: a panel data study. World Academic of Science, Engineering and Technology, 50, PP 1073-1078.

10. Behera, J. (2014). Inflation and its Impacts on Economic Growth: Evidence from Six South Asian countries. Journal of Economics and Sustainable Development.Vol 5, No 7. PP 145-154. www.iiste.org

11. Borensztein,E., De Gregoria J. and Lee, J.W. (1998). How does foreign direct investment affect economic growth? Journal of International Economics, Vol. 45, No 1, PP 115-135.

12. Bruno, M. and Easterly, W. (1998).Inflation Crisis and Long-run Growth. Journal of Monetary Economics, 41(1), PP 3-26.

13. Chen, H. (2009). A literature review on the relationship between foreign trade and economic growth. International Journal of Economics and Finance, PP 127-130.

14. Chantal, L, Huchet-Bourdon, M. and Vijil, $M$. (2011). The relationship between trade openness and economic growth: some new insights on the openness measurement issue. X III eme congress de l'association europeenne des economist Agricoles (EAAE), Zurich $(\mathrm{CH})$, Switzerland 
15. Drezgic, S.(2008).The effects of public sector investments on economic growth in Croatia, University of Rijeka, Croatia .

16. De Gregorio J. (1993). Inflation, Taxation and Long-run Growth. Journal of Monetary Economics, 31(3), PP 217-298.

17. Dowrick, S, and Golley, J. (2004). Trade Openness and Growth: Who Benefits? Oxford Review of Economic Policy, Vol. 20, No. 1, PP 38-56

18. Dobre, C. (2008). The Relation Between Openness of Trade and Economic Growth. Central and Eastern European Online Library.

19. Faiza,U.(2014). Impact of Trade openness on economic growth of Pakistan: An ARDL approach. Journal of Business and Economic Policy, Vol 1, No 1 pp.39-59, Applied Economic Research Centre.

20. Fischer, S. (1993). The Role of Macroeconomic Factors in Economic Growth. Journal of Monetary Economics, Vol 32, No. 2, PP 485-512.

21. Fikadu,S.H.(2017).Effect of Trade Openness on Economic Growth in Case of Sub-Saharan African Countries: A Panel Data Approach.(Unpublished Masters Project in Economics), Makerere University, Kampala Uganda.

22. Gisore, N. M. (2014). Effect of Government Expenditure on Economic Growth in East Africa: A Disaggregated Model. (Unpublished Masters Thesis in Economics), Egerton University, Kenya.

23. Grossman, G. and Helpman, E. (1991). Innovation and Growth in the World Economy. Cambridge MIT.

24. Githiga,M.E. (2014).Impact of Remittances inflows on economic growth in Kenya. Unpublished masters Research project in economics), University of Nairobi, Nairobi, Kenya.

25. Gylfason, T. and Herbertson, T.T (2001). Does Inflation Matter for growth? Japan and the World Economy.Vol 13, PP 405-428

26. Halima, I.(2015).Effects of external public debt on economic growth: An empirical analysis of East African countries.(Unpublished Masters Research Project in Economics), University of Nairobi, Kenya.

27. Hausman, Hwang and Rodrick(2007). What you export matters. Journal of Economic Growth, PP 1 25.

28. Harrison, A, (1996). Openness and growth: a time series, cross country analysis for developing countries. Journal of Development Economics, PP. 419-447.

29. Hidayat, A.S., Suman,A., and Kaluge,D.(2014).The Effect of Interest rates, Inflation and Government Expenditure on Economic Growth in Indonesia period of 2005-2012. Journal of Economics and sustainable development. Vol 5. No 15, PP.243-249. www.iiste.org.

30. Haystad, J.T and Jensa, H.G.(2015). Economic growth, is openness to international trade beneficial? Norwegian School of Economics, pp. 172 .
31. Jarque, M., and Bera, K. (1980). Efficiency Tests for Normality, Homoscedasticity. Math Works.

32. Josaphat,P. and Oliver, M.(2000). Government Spending and Economic Growth in Tanzania, 19651996, Credit Research Paper.

33. Kweka,P. and Morrissey,O. (1999). Government Spending and Economic Growth: Empirical Study from Tanzania( 1965-1996), CREDIT and School of Economics, University of Nottingham.

34. Kormandi,R.C. and Maguire, P.G (1983). Macroeconomic determinants of growth: crosscountry evidence. Journal of Monetary Economics, 16(2), PP 141-163.

35. Karen,P.(2015). What is trade openness and what is the effect of trade openness on economicl financial development? Retrieved from Karyth Cara.Enotes, 21, https://www.enotes.com/homework-help/whattrade -openness-87695.

36. Krugman, P., Obstfeld, M. (2007). International Economics: Theory and Policy. Financial Theory and Practice. 31(3) PP 317-318.

37. Lam, T.D (2015). A review of modern international trade theories. American Journal of Economics, Finance and Management. PP 604-613.

38. Limam, $Y, \&$ Miller, S.(2003). Explaining economic growth: factor accumulation, total factor productivity growth, and production efficiency improvement, University of Nevada, Las Vegas.

39. Malefa, R.M. \& Odhiambo,N.M. (2018). Impact of trade openness on economic growth.: empirical evidence from South Africa.UNISA Economic Research Working Paper Series, No. 5 University of South Africa Pretoria.

40. Mankiw, N., Romer, D and Weil, D.N. (1993). A contribution to the empirics of economic growth. The Quarterly Journal of Economics, PP 407-437.

41. Macias, B.J and Massa, I. and Murinde, V. (2009). Cross-border lending versus FDI in Africa's growth story. A Paper Presented at the African Economic Conference in November, Addis Ababa, Ethiopia.

42. Mbabazi, M. Morrisey. (2004). Trade Openness, Trade Cost and Growth: Why Sub-Saharan Africa Performs Poorly. Credit Research Paper, PP 1-21.

43. Mputu,C. (2016). Terms of trade, trade openness and economic growth in Sub-Saharan Africa St.Cloud State University, pp. 10-20

44. Muhammad, T. and Toseef A. (2015). The Relationship Between International Trade Openness and Economic Growth. Journal of Chinese Economic and Foreign Trade Studies, PP 123-139. Retrieved from https://doi.org/10.1108/JCEFTS-02-2015-0004

45. Munyambonera,E.F.(2012).Determinants of Commercial Bank Performance in Sub-Saharan Africa.(Unpublished PhD Thesis in Economics),Makerere University, Kampala, Uganda.

46. Osei, Y.,Cephas,N.\& Shaik,S.(2012)Effect of trade openness on economic growth: The case of African 
countries. Paper Presented at the Southern Agricultural Economics Association Annual Meeting, Al Feb 4-7.

47. Ofosuah, S.D.(2014).Effects of government spending on economic growth for Sub-Saharan Africa. (Unpublished Masters thesis in the economics) University of Ghana, legon, Ghana.

48. Panayiotis,P., Anthanasoglou, S., Brissimis, N. and Mathaios,D.D. (2005).Bank Specific, IndustrySpecific and Macroeconomic Determinants of Bank Profitability, Bank of Greece Working Paper, No 25.

49. Ray,S.(2012).Determinants of total factor productivity growth in selected manufacturing industries in India. Research and Social practices in Social Sciences. 7(2), PP 25-43.

50. Saibu, M.O. (2004). Trade openness and economic growth in Nigeria. Further evidence in the causality issue .SAJEMS SN.7, No 2 pp. 229-315. Department of economics, Obufemi, Awolowo University.

51. Sala, H.P. (2014).Openness, Investment and Growth in Sub-Saharan Africa. Journal of African Economics. PP 1-33.

52. Salama, Y.,\&Moza,R.O. (2019). Trade openness and economic growth of Tanzania. Asian Journal of Economics Business and Accounting, 12(3), ppl10.AJEBA.

53. Semwanga, J.P. (2011). Foreign Direct Investment and Economic Growth. The Case of Uganda (19702007).(Unpublished Masters Dissertation in Economics),Makerere University.Kampala, Uganda.

54. Sundaram,J., and Arnim, R.(2008).Economic liberalization and constraints to development in Sub-Saharan Africa.DESA Working Paper, No. 67.

55. Taleb,T.T. and Hala,T.(2019).The Impact of the Exchange, Interest and Inflation Rates on Economic Growth: The Case of Arab Republic of Egypt. Journal of Economics and sustainable Development.Vol 10, No 12. PP 56-66. www.iiste.org.

56. Todaro, S. (2005). Development economics $9^{\text {th }}$ edition. Bristol, United Kingdom: AddisonWesley $(E)$
57. Tadesse, A. (2012). The nexus between public investment, private investment, trade openness and economic growth in Ethiopia, Addis Ababa University, Ethiopia.

58. Valdovinoz, C.G.F (2003). Inflation and economic growth in the long-run. Economic letters. (80) PP 157-173.

59. Zekarias, S.M. (2016).The Impact of Foreign Direct Investment on Economic Growth on East African Countries: Evidence from Panel Data Analysis. Applied Economics and Finance, PP145-160.

\section{APPENDIX}

Table 1: Autocorrelation test

\begin{tabular}{|c|c|c|c|}
\hline $\begin{array}{c}\text { Estimated } \\
\text { model } \\
\text { tables }\end{array}$ & $\begin{array}{c}\text { Order of } \\
\text { correlation }\end{array}$ & $\begin{array}{c}\mathbf{Z} \\
\text { statistics }\end{array}$ & $\operatorname{Pr}>\mathbf{z}$ \\
\hline Table 4.5 & $\mathrm{AR}(1)$ & $\mathrm{z}=-$ & $\operatorname{Pr}>\mathrm{z}=$ \\
& & $6.54^{* * *}$ & 0.000 \\
\hline Table 4.5 & $\mathrm{AR}(2)$ & $\mathrm{z}=-0.99$ & $\operatorname{Pr}>\mathrm{z}=$ \\
& & $\mathrm{z}=-321$ \\
\hline Table 4.6 & $\mathrm{AR}(1)$ & $6.32^{* * *}$ & $\mathrm{Pr}>\mathrm{z}=$ \\
& & $\mathrm{z}=-1.07$ & $\operatorname{Pr}>\mathrm{z}=$ \\
& & $\mathrm{z}=-$ & $\mathrm{Pr}>\mathrm{z}=$ \\
& & $6.81^{* * *}$ & 0.000 \\
\hline Table 4.6 & $\mathrm{AR}(2)$ & $\mathrm{z}=-1.02$ & $\mathrm{Pr}>\mathrm{z}=$ \\
& $\mathrm{AR}(1)$ & & 0.309 \\
\hline Table 4.7 & $\mathrm{AR}(2)$ & &
\end{tabular}

Source:Research Data

NOTE ***,*** indicates rejection of the null hypothesis that all panels contain unit roots at 1\%,5\% and $10 \%$ level of significance respectively.The number in parenthesis is the $p$-value 
Table 2: Im Pesaran and Shin Panel Unit Root Test

\begin{tabular}{|c|c|c|c|}
\hline Variable & $\begin{array}{c}\text { Level } \\
\text { First diff }\end{array}$ & Constant & $\begin{array}{l}\text { Constant } \\
\text { +trend }\end{array}$ \\
\hline \multirow[t]{2}{*}{ LNGDP } & Level & $\begin{array}{c}-4.1577^{* * *} \\
(0.0000)\end{array}$ & $\begin{array}{c}-1.1377 \\
(0.1276)\end{array}$ \\
\hline & $1^{\text {ST }}$ diff & & $\begin{array}{c}4.8538^{* * *} \\
(0.0000\end{array}$ \\
\hline \multirow[t]{2}{*}{ TOPEN } & Level & $\begin{array}{c}0.1926 \\
(0.5764) \\
\end{array}$ & $\begin{array}{c}1.1523 \\
(0.8754) \\
\end{array}$ \\
\hline & $1^{\text {ST }}$ diff & $\begin{array}{c}-6.7042^{* * *} \\
(0.0000)\end{array}$ & $\begin{array}{c}-4.6304^{* * *} \\
(0.0000)\end{array}$ \\
\hline POPL & Level & $\begin{array}{c}-12.2821^{* * *} \\
(0.0000)\end{array}$ & $\begin{array}{c}-28.6494^{* * *} \\
(0.0000)\end{array}$ \\
\hline \multirow[t]{2}{*}{ FDI } & Level & $\begin{array}{c}-2.5697^{* *} \\
(0.0051)\end{array}$ & $\begin{array}{l}-0.2855 \\
(0.3876)\end{array}$ \\
\hline & $1^{\text {ST }}$ diff & & $\begin{array}{c}-5.4751^{* * *} \\
(0.0000)\end{array}$ \\
\hline LNGCF & Level & $\begin{array}{c}-10.4478^{* * *} \\
(0.0000)\end{array}$ & $\begin{array}{c}-5.7838^{* * *} \\
(0.0000)\end{array}$ \\
\hline LNDOM1 & Level & $\begin{array}{c}-12.0490^{* * *} \\
(0.0000)\end{array}$ & $\begin{array}{c}-9.6912^{* * *} \\
(0.0000)\end{array}$ \\
\hline LNNODA1 & level & $\begin{array}{c}-2.0872^{* *} \\
(0.0184)\end{array}$ & $\begin{array}{c}-1.7582^{* *} \\
(0.0394)\end{array}$ \\
\hline LNINFL & level & $\begin{array}{c}-5.6904^{* * *} \\
(0.0000)\end{array}$ & $\begin{array}{c}-4.7444^{* * *} \\
(0.0000)\end{array}$ \\
\hline
\end{tabular}

Source:Research Data

NOTE $* * *, * * *$ indicates rejection of the null hypothesis that all panels contain unit roots at $1 \%, 5 \%$ and $10 \%$ level of significance respectively.The number in parenthesis is the p-value 
Table 3: Effect of inflation on GDP in SSA

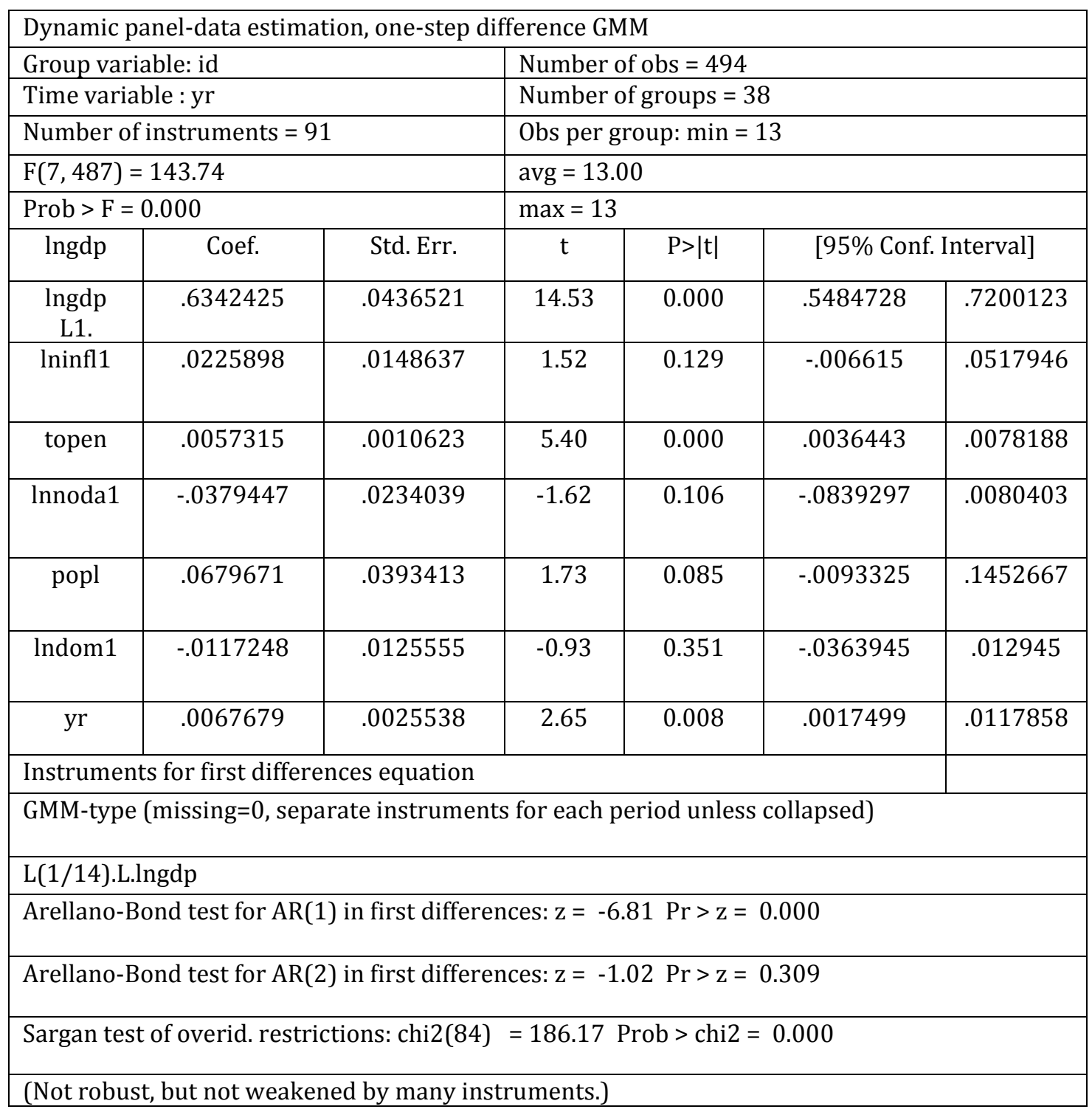

Source:Reseach data 
Table 4

DESCRIPTIVE STATISTICS

Effect of Trade Openness on GDP in SSA Source: Research data

\begin{tabular}{|l|c|c|c|c|c|c|c|c|}
\hline & LNGDP & LNGCF1 & LNDOM1 & LNINFL1 & LNNODA1 & POPL & TOPEN & FDI \\
\hline Mean & 7.104726 & 5.141826 & 5.252732 & 5.219661 & 5.352815 & 2.549233 & 73.40129 & $7.85 \mathrm{E}+08$ \\
\hline Median & 6.884690 & 5.585373 & 5.622210 & 5.551018 & 5.654241 & 2.696215 & 64.21301 & $3.41 \mathrm{E}+08$ \\
\hline Maximum & 10.04075 & 6.311735 & 6.329721 & 6.295266 & 6.345636 & 4.654911 & 225.0231 & $1.00 \mathrm{E}+10$ \\
\hline Minimum & 4.854657 & 0.000000 & 0.000000 & 0.000000 & 0.000000 & -2.628656 & 0.000000 & $-7.40 \mathrm{E}+09$ \\
\hline Std. Dev. & 1.084353 & 1.355355 & 1.176640 & 1.020803 & 0.978101 & 0.907697 & 35.50063 & $1.59 \mathrm{E}+09$ \\
\hline Skewness & 0.737476 & -2.276839 & -2.278090 & -1.476957 & -1.800660 & -1.194419 & 1.215380 & 1.977772 \\
\hline Kurtosis & 2.794736 & 8.489814 & 9.350176 & 5.489608 & 7.101289 & 5.790813 & 5.121711 & 14.80395 \\
\hline Jarque-Bera & 52.66833 & 1208.258 & 1450.734 & 354.4391 & 707.5144 & 320.5106 & 247.2435 & 3680.764 \\
\hline Probability & 0.000000 & 0.000000 & 0.000000 & 0.000000 & 0.000000 & 0.000000 & 0.000000 & 0.000000 \\
\hline Sum & 4049.694 & 2930.841 & 2994.057 & 2975.207 & 3051.105 & 1453.063 & 41838.74 & $4.48 \mathrm{E}+11$ \\
\hline Sum Sq. Dev. & 669.0429 & 1045.245 & 787.7704 & 592.9206 & 544.3520 & 468.8072 & 717107.7 & $1.44 \mathrm{E}+21$ \\
\hline Observations & 570 & 570 & 570 & 570 & 570 & 570 & 570 & 570 \\
\hline
\end{tabular}

Source: Reseach data 